\title{
Physicochemical and Proximate Analysis of Extracts from Citrus sinensis of Dutsinma, Katsina State, Nigeria
}

\author{
Gnimintakpa Joseph, Sa'ada Abdullahi \\ Department of Biochemistry and Molecular Biology, Federal University, Dutsinma, Nigeria \\ Email: Gniminsco@yahoo.co.uk
}

Received 4 March 2016; accepted 20 March 2016; published 25 March 2016

Copyright (C) 2016 by authors and OALib.

This work is licensed under the Creative Commons Attribution International License (CC BY). http://creativecommons.org/licenses/by/4.0/

(c) (i) Open Access

\section{Abstract}

This paper performed the physicochemical and proximate analysis of the extracts isolated from Citrus sinensis from Dutsinma local government area of Katsina state in Nigeria. Characteristics of the seeds were investigated by Association of Official Analytical Chemists (AOACs). The seeds were found to be potential raw materials for livestocks nutrition, cosmetic manufacturing and construction industries. The physicochemical parameters included oil percentage yield, melting point, specific gravity, iodine value, saponification value, peroxide value, free fatty acid value, and acid value. The proximate parameters included moisture, protein, carbohydrate, crude fiber, and ash content. This study concluded that Citrus sinensis seed could be utilized as potential raw material for oil producing industries.

\section{Keywords}

Citrus sinensis Seeds, Physicochemical, Proximate, Analysis, Dutsinma, Nigeria

Subject Areas: Biochemistry, Molecular Biology

\section{Introduction}

Concern continues to grow as to insufficient supply of fat in the diet of an average Nigerian (FAO, 1992) [1]. One of the possible ways of closing the gap between the need and supply is through extraction of this commodity from the residues (seeds) of locally produced fruits. Massive supply of fruits in Dutsinma, Katsina State, Nigeria is, however, restricted by insufficient and exclusive supply of rain water as it is always the case in savannah region (Hasssan et al., 2013) [2] and total absence of irrigation system. Even as efforts to identify residues (seeds) of drought resilient plants (Ingram et al., 1996) [3] and conserve existing ones already known with these attributes gain new momentum, extant research work observes that increasing mechanization of crop farming in 
developing countries has led to a rise in the tonnage of agro-allied products, most of which lie waste (Hon et al., 2009) [4]. One of such wastes could emanate from Citrus sinensis, a major fruit of sub-tropical region (Rice and Rice, 1987; Hon et al., 2009) [4] [5]. There is significant evidence supporting the large production of Citrus sinensis with heavy direct consumption due primarily to non-existent processing capacity to convert the fruits in juice. Nigeria produces 3\% of fresh citrus in the world and Africa produces 3,741,000 tons (Hon et al., 2009) [4] varieties of citrus fruits of which Nigeria contributes 3,240,000 tons (FAO, 2004; Hon et al., 2009) [1] [4]. The increase in the production of Citrus sinensis residues (seeds) correlates with the production growth in food industries. These residues originated from in-nature consumption are often totally discarded, causing problems of environmental contamination because the waste is more likely to be degraded by microorganisms (Patricia et al., 2015) [6]. Thus the use of these residues in an efficient, economic and environmentally safe manner is especially important in view of their potential profitability (Schieber et al., 2001; Patricia et al., 2015) [6] [7].

This work aimed to investigate the proximate and phytochemical properties of extracts from Citrus sinensis residues given their economic and commercial potential, assess the quality of the oil and cake so extracted and determine the industry best suited for their use.

\section{Materials and Methods}

\subsection{Reagents}

All reagents used for this study were pure and of analytical grade.

\subsection{Sample Collection}

To this end, five kilograms of residues of Citrus sinensis were handpicked by the Department of Agroforestry of the Katsina state Ministry of Environment from residues from a gallery forest of orange trees in April 2015 after identification and characterization of the trees by a plant scientist from Musa Yar'adua University, Katsina.

\subsection{Sample Preparation}

The usable residues were scavenged de-shelled, washed and well dried under room temperature for two weeks prior to pulverization which is the last preparation stage with the aid of a blending machine and stored in a container for further use.

\subsection{Extraction}

The Soxlet extraction tank, Pilotech YC-020 manifactured by Shanghai Pilotech Instrument Equipment Co., LTD, Rm 1603, Building B Everwin Garden 521 WanpingNan Rd was used for this purpose. A 5 liter capacity soxhlet mechanism was loaded with $200 \mathrm{~g}$ grams of pulverized residues packed in a whatman filter paper and inserted into the soxhlet extractor with a $40^{\circ} \mathrm{C}-60^{\circ} \mathrm{C}$ petroleum ether (BDH analar grade) used as the extracting solvent, the process period extention scaled to 16 hours. At the end of this exercise, the solvent was recovered by simple distillation and the residual oil oven-dried at $65^{\circ} \mathrm{C} \pm 2^{\circ} \mathrm{C}$ for one hour. The oil was then transferred to a desicator and allowed to cool, before being weighed while the cake was preserved. The drying, cooling and weighing cycle was triplicated until a constant dry weight of 0.01 gramme of oil golden yellow colour was obtained. This extraction principle was solely based on the use of organic solvent which once heated dissolves the lipid samples.

Physicochemical properties

Further on in this study, we investigated the presence of physico-chemical components in the oil extracts and carefully evaluated proximate properties in accordance with the following principles and protocols.

Determination of oil yield

The total amount of the oil extracted from residues was determined by using the equation:

$$
\text { Percentage yield : } \frac{\left(W_{2}-W_{1}\right) * 100}{W_{3}}
$$

$W_{1}$ : Weight of the flask alone;

$W_{2}$ : Weight of flask and oil;

$W_{3}$ : Actual weight of residues from Citrus sinensis used (Nwokonkwo, 2013) [8]. 
Determination of melting point

$1 \mathrm{~cm}^{3}$ of Citrus sinensis residues oil was introduced into a capillary tube and frozen and allowed to stand at room temperature until the oil melted at temperature that was recorded as the melting point.

Determination of specific gravity [8]

The specific gravity was determined by weighing an empty $25 \mathrm{~cm}^{3}$ density bottle. The bottle was filled to mark with oil and weighed thereafter. The same experiment was carried out by filling the same density bottle to mark with distilled water after washing and rincing it with distilled water.

The specific gravity was then derived using the following equation

$$
\text { Specific gravity }=\frac{W_{1}}{W_{2}}
$$

$W_{1}$ : Weight of oil;

$W_{2}$ : Weight of distilled water [8];

Saponification value determination

Saponification value was determined following the protocol prescribed by AOAC (2009) [9]. We filtered oil through the filter paper to remove impurities and weighed accurately $5 \mathrm{~g}$ of oil into $250 \mathrm{ml}-300 \mathrm{ml}$ flask connected to the condenser and recorded the weight of the sample. We accurately added $50 \mathrm{ml}$ of alcoholic $\mathrm{KOH}$ into the flask. Also we prepared a blank by just adding $50 \mathrm{ml}$ of alcoholic $\mathrm{KOH}$ into 250 - $300 \mathrm{mls}$ flask and added several boiling beads to the flask with oil sample. Thereafter the flask was connected to the condenser and boiled gently but steadily on water bath until the sample is clear and homogeneous indicating complete saponification. The sample was then allowed to cool. The inward part of the condenser was washed with a little deionized distilled water. We disconnected the flask from the condenser and allowed the sample to cool at room temperature. We then added $1 \mathrm{ml}$ phenolphthalein to the mixture and performed titration using $0.5 \mathrm{~N}$ HCL from a buiret until the pink color gradually disappeared and the volume of titrant was recorded. Steps starting from boiling beads to titration were repeated with the sample blanks while refluxing them the same way and number of times as was done to samples.

\subsection{Iodine Value Determination}

Iodine value is a measure of degree of unsaturation defined as grams of iodine absorbed per 100 grams of sample. This value was determined in accordance with the AOAC [9] established method number 942.27 by filtering the oil sample through a filter paper to remove impurities and accurately measuring $0.1-0.5 \mathrm{~g}$ of sample (depending on the expected iodine number) into a dry $500 \mathrm{ml}$ glass stoppered flask. We then added $10 \mathrm{ml}$ chloroform to dissolve the oil. In addition we prepared a blank by adding only $10 \mathrm{ml}$ chloroform to $500 \mathrm{ml}$ glass stoppered flask. We then pipetted $25 \mathrm{ml}$ wijs iodine solution into the flask. The amount of Iodine was $50 \%$ $60 \%$ in excess of that absorbed by the fat. Flasks were kept standing in the dark for 30 minutes and occasionally shaken. Thereafter, $20 \mathrm{ml}$ potassium iodide was added to each flask and shaken thoroughly. $100 \mathrm{ml}$ of boiled and cooled water was added to wash down free iodine on the stopper. Titration of iodine in the flask followed using sodium thiosulfate, gradually added with constant and vigorous shaking until yellow color gradually disappeared. We then added $1-2 \mathrm{ml}$ of starch indicator and continued the titration until the blue color entirely disappeared. Towards the end of the titration, we corked the flask and shook violently so that any iodine remaining in the chloroform could be taken up by the potassium iodide solution and recorded the volume of titrant used and the calculated iodine value.

\subsection{Free Fatty Acid Value Determination}

Acid value reflects the amount of fatty acids hydrolyzed from tryacylglycerols.

This value was determined by adding to oil sample $100 \mathrm{ml} 95 \%$ neutralized ethanol and $2 \mathrm{ml}$ phenolphthalein indicator. After shaking for the mixture to dissolve, titration follows using $0.1 \mathrm{~N} \mathrm{NaOH}$ and shaking vigorously until the endpoint is reached. This is indicated by a slight pink color that persists for 30 seconds AOACs (2009) [9].

-Peroxide value estimation

Peroxide is defined as the milliequivalent of peroxide per kilogram of fat as determined in a titration procedure to measure the amount of peroxide or hydroperoxide groups. 
Peroxide value was estimated in accordance with the following procedure, as prescribed by AOAC [9] (2009). We filtered melted oil sample though the filter paper to remove impurities and accurately weighed $5 \mathrm{~g}$ of oil to the nearest $10^{-3}$ into $250 \mathrm{mls}$ glass stoppered Erlenmeyer flask. We then added $30 \mathrm{mls}$ acetic acid chloroform and swirl to dissolve and also added $0.5 \mathrm{ml}$ saturated KI solution and allowed to stand for 1 minute while occasionally shaking, and added $30 \mathrm{mls}$ of distilled water. We then slowly titrated the sample with $0.1 \mathrm{~N}$ sodium thiosulfate with vigorous shaking until yellow color disappeared. Thereafter we added $0.5 \mathrm{ml} 1 \%$ starch solution and continued titration, shaking vigorously to release all iodine from chloroform layer until blue color disappeared and recorded the volume of titrant used.

-Proximate composition determination

\subsection{Moisture Content Determination}

An empty crucible was cleaned and dried in an oven and then filled with two grams (2 g) of pulverized sample in the same oven at $105^{\circ}$ until a constant weight is attained. The moisture content was calculated as a loss in weight of the original sample and expressed in percentage of moisture content (FAO, 2004; Udeme et al., 2013) [1] [10].

Determination of crude protein

Crude protein in the pulverized seeds residues was determined using Kjeldahl method with some changes. 0.5 grams of pulverized residues were digested with $5 \mathrm{mls}$ of concentrated sulfuric acid in the presence of Kjeldahl catalyst. The nitrogen from protein in the sample was converted into ammonium sulfate that reacted with $2.5 \mathrm{mls}$ of $2.5 \%$ Brucine reagent, made up of $5 \mathrm{mls} 98 \%$ sulfuric acid to give a colored derivative with the absorbance determined at $470 \mathrm{~nm}$. The percentage nitrogen was then calculated and multiplied by 6.25 to obtain the crude protein [9] [10].

Estimation of crude lipid from residues

This estimation was executed using Soxhlet extraction method. Two (2) grams of powdery form of residues were weighed, wrapped in a filter paper and placed in a thimble, covered with cotton wool and placed in an extraction column connected to a condenser. $40 \mathrm{mls}$ of $\mathrm{n}$ - hexane were used to extract crude lipids [9] [10].

Determination of crude fiber from residues [9] [10].

This was achieved by using AOAC method. Five (5) grams of pulverized residues and $200 \mathrm{mls}$ of $1.25 \%$ $\mathrm{H}_{2} \mathrm{SO}_{4}$ were heated for thirty (30) minutes and filtered with a Buchner funnel the remainder was washed with distilled water until it is acid free. $200 \mathrm{mls}$ of $1.25 \% \mathrm{NaOH}$ was also boiled along with the same remainder for thirty (30) minutes. The mixture was also filtered and washed several timesa until it was alkaline free. It was then rince with $10 \% \mathrm{HCl}$ once and twice with ethanol. At the end of the protocol, the remainder was rinsed with petroleum ether three (3) times, put in a crucible and dried at $105^{\circ} \mathrm{C}$ in an oven all through the night. After cooling in a dessicator, the remainder was ignited in a muffle furnace at $550^{\circ} \mathrm{C}$ for ninety (90) minutes to obtain the weight of the ash.

Determination of ash content from residues

In accordance with the method of AOAC [9], the total ash content is the percentage of inorganic residue left after the organic substance has been ignited. Two (2) grams of pulverized residue sample was placed in a crucible and ignited in a muffle furnace at $500^{\circ} \mathrm{C}$ for six hours. The residue was then cooled in a dessicator and weighed at room temperature to determine the weight of ash.

Carbohydrate determination from residues

The carbohydrate content was determined by subtracting the summed up percentage composition of moisture, protein, lipid, fiber and ash content from 100 [10] [11].

\subsection{Statistical Analysis}

The results of physicochemical and proximate analyses were expressed as means \pm standard error.

\section{Results}

The physicochemical analyses of oil from residues revealed the following results (Table 1).

Proximate analysis showed the following results.

The proximate parameters in pulverized residues were tabulated (Table 2) below. 
Table 1. Physicochemical results from oil extracts from residues of Citrus sinensis.

\begin{tabular}{cc}
\hline Properties & Values \\
\hline Oil percentage yield & $36 \pm 0.05$ \\
Melting Point & $9.920 \pm 0.020$ \\
Specific gravity & $0.916 \pm 0.010$ \\
Saponification value & $198 \pm 0.020$ \\
Iodine Value & $118 \pm 0.001$ \\
Peroxide Value & $18.8 \pm 0.010$ \\
Free Fatty acids & $3.1 \pm 0.020$ \\
Acid Value & $1.3 \pm 0.050$ \\
\hline
\end{tabular}

Table 2. Results of proximate analysis from pulverized residues of Citrus sinensis.

\begin{tabular}{ccc}
\hline Nutrients & Values in percentage \\
\hline Moisture & $2.4 \pm 0.002$ \\
Protein & $4.82 \pm 0.015$ \\
Carbohydrate & $7.6 \pm 0.001$ \\
Crude fiber & $19.70 \pm 0.010$ \\
Ash & $14.76 \pm 0.001$ \\
\hline
\end{tabular}

\section{Discussion}

The chemical characteristics of Citrus sinensis seeds oil were evaluated by the following parameters, acid, iodine, saponification, specific gravity, melting point, free fatty acids and percentage oil yield as presented in Table 1 above.

The percentage oil yield of 36 was higher than 27.845 reported for Cussonia batery by Nwokonkwo (2013) [8] and lower than 37 \% for rubber (Hevea brasiliensis, cultivar RRIM 600)'s seed oil as reported by Kittigowittana and his colleague in (2013) [12]. Citrus sinensis seed could therefore be considered as potential raw material for oil producing industries.

The saponification value of $198 \mathrm{mg} \mathrm{KOH/g}$ of oil obtained from Citrus sinensis seeds agrees with values for most vegetable oils ranging from 188 - $253 \mathrm{mg} \mathrm{KOH/g} \mathrm{(Oluba} \mathrm{et} \mathrm{al.,} \mathrm{2008;} \mathrm{Otasie} \mathrm{and} \mathrm{Akinhanmi,} \mathrm{2009;} \mathrm{Nwo-}$ konkwo, 2013) [8] [13] [14]. This indicates that oil from Citrus sinensis seeds has high potential for soap and shampoos producing purpose (Ku and Mun, 2007) [15]. This value of $198 \mathrm{mg} \mathrm{KOH/g}$ was low compared to other oils like coconut oil (253.4 - 263.0), palm oil (200 - 205), palm kernel oil (243 - 263). This classifies Citrus sinensis oil not among the best raw materials for the production of soap and other detergents. The specific gravity of Citrus sinensis oil of 0.916 was close to those of Cussonia battery's oil (0.917), linseed oil's (0.938) and beeswax oil's (0.953) (Nwokonkwo, 2013) [8]. The oil's iodine value of 118 signals unsaturation, as a drying oil, could be used industrially for the production of paints and perfumes. The acid value determined the extent to which glycosides in the oil have been decomposed by lipases (Dosumu et al., 1996; Nwokonkwo, 2013) [8] [16]. The content of $1.3 \mathrm{mg}$ and the value of free fatty acid $3.1 \mathrm{mg}$ could be compared to Bussonia battery oil (2.805 mg) and mango seed oil (1.1 mg). This is a very strong factor in rancidity caused by oxidation and shelf life span.

\section{Proximate Investigation}

The percentage protein for instance of $4.82 \%$ is far below $16 \%$ - $17 \%$ reported as best for rabbit performance in tropical environment (Anugwa et al., 1982; Aduku and Olukosi, 1990) [17] [18].

The crude fiber of $19.70 \%$ may not facilitate nutrient digestibility, in line with the findings of Adegbola and 
Okonkwo (2002) [18], who demonstrated a negative correlation coefficients between crude fiber and nutrient digestibility, indicating that high crude fiber figure in the diet depresses nutrient digestibility (Hon et al., 2003) [4]. The moisture content of any seed is an index of water activity therein and is considered as stability factor and microbial contamination facilitator. Moisture content of $2.4 \%$ in the seeds of Citrus sinensis depicted the resilience of these seeds to seasonal fluctuations as high moisture content can be responsible for rapid deterioration (Ogoloma et al., 2013) [10]. The ash content is an indication of minerals present in a sample. The percentage content of 14.76 of ash in Citrus sinensis seed from Dutsinma in Katsina State Nigeria is much greater than 0.63 and 0.49 for Benue and River States Oranges respectively. The percentage of carbohydrate of 7.60 is below the percentage content of carbohydrate in orange fruits of $9.30 \%$ and $7.71 \%$ from Benue State (BS) and River state (RS) respectively in Nigeria.

\section{Conclusion}

Physicichemical and proximate analysis of extracts from residues of Citrus sinensis from Dutsinma Local Government Area of Katsina State in Nigeria shows great nutritional attributes and makes Citrus sinensis a potential raw material for cosmetic, construction and livestock food industries. The use of these seeds will greatly abate global warming by mitigating environmental pollution caused by their decomposition to a minimal level. However, further research is recommended on Citrus sinensis seeds employing specific enzymes (Victor Markus et al., 2014) [19] to determine their phytochemical composition.

\section{References}

[1] FAO (1980) Compositional Analysis Methods. In: Manuals of Food Quality Control, Food Analysis General Techniques, Additives, Contaminants and Composition of Food and Agricultural Organization of the United Nations, FAO, Rome, 203-232.

[2] Ishaku, H.T., Abayomi, A.P., Sahabo, A.A. and Dama, f.M. (2013) Complementimg Water Supply through Rain Water Harvesting in Some Selected Villages of Sahel Savannah Ecological Zone of Borno State North Eastern Nigeria. Journal of Water Resource and Protection, 5, 200-207. http://dx.doi.org/10.4236/jwarp.2013.52021

[3] Ingram. J. and Bartels, D. (1996) The Molecular Basis of Dehydration Tolerance in Plants. Annual Review of Plant Physiology and Plant Molecular Biology, 47, 377-403. http://dx.doi.org/10.1146/annurev.arplant.47.1.377

[4] Hon, F.M., Oluremi, O.I.A. and Anugwa,, F.O.I. (2009) The Effect of Dried Sweet Orange (Citrus sinensis) Fruit Pulp Meal on the Growth Performance of Rabbits. Pakistan Journal of Nutrition, 8, 1150-1155. http://dx.doi.org/10.3923/pjn.2009.1150.1155

[5] Rice, R.P. and Rice, L.W. (1987) Fruits and Vegetables Production in Africa. Bunda College of Agriculture, Malawi.

[6] Nunes, P.M.P., Da Silva, C.B., Da Silva Paula, C., Smolarek, F.F., Zeviani, W.M., Shaves, S.C., Lorini, F., Dias, J.F.G., Miguel, O.G., Zanin, S.M.W. and Miguel, M.D. (2015) Residues of Citrus sinensis (L.) Osbeck as Agents that Cause a Change in Antioxidents Defense in Plant. Brazilian Journal of Pharmaceutical Sciences, 51, 479-493.

[7] Schieber, A., Stintzing, F.C. and Carles, R. (2001) By-Products of Plants Food Processing as a Source of functional Compounds: Recent Developments. Trends in Food Science \& Technology., 12, 401-413. http://dx.doi.org/10.1016/S0924-2244(02)00012-2

[8] Nwokonkwo, D.C. (2013) Physicochemical and Phytochemical Studies of the Constituents of the Seed of Cussonia bateri (Jansa Seeds). American Journal of Scientific and Industrial Research, 4, 414-419.

[9] AOAC (1990) Official Methods of Analysis of the AOAC. 15th Edition, Association of Official Analytical Chemists, Washington DC.

[10] Ogoloma, U.J., Nkpaa, K.W., Akininwor, J.O. and Uwakwe, A.A. (2013) Proximate Phytochemical and Mineral Elements Composition of Some Edible Fruits Grown in Oil Producing Community of River State Nigeria. IOSR Journal of Environmental Science, Toxicology and Food Technology, 5, 38-46. http://dx.doi.org/10.9790/2402-0523846

[11] Otitoju, G.T.O. (2009) Effects of Dry and Wet Milling Processing Techniques on Nutrient Composition and Organoleptic Attributes of Fermented Yellow Maize (Zea mays). African Journal of Food Sciences, 3, 113-116.

[12] Kittigowittana, K., Wongsakul, S., Krisdaphong, P., Jimtaisong, A. and Saewan, N. (2013) Fatty Acids Composition and Biological Activities of Seed Oil from Rubber (Hevea brasiliensis) Cultivar RRIM 600. International Journal of Applied Research in Natural Products, 6, 1-7.

[13] Oluba, O.M., Ogunlowo, Y.R., Ojieh, G.C., Adebisi, K.E., Eidangbe, G.O. and Isiosiol, I.O. (2008) Physicochemical Properties and Fatty Acid Composition of Citrullus lanatus (Egusi Melon) Seed Oil. Journal of Biological Sciences, 8, 814-817. 
[14] Otasie, V.N. and Akinhanmi, T.F. (2009) Extraction, Compositional Studies and Physicochemical Characteristics of Palm Kernel Oil. Pakistan Journal of Nutrition, 8, 800-803. http://dx.doi.org/10.3923/pjn.2009.800.803

[15] Ku, C.S. and Mun, S.P. (2007) Characterization of Seed Oils from Fresh Bok Bunja (Rubus coreanus miq) and Wine Processing Waste. Bioresource Technology, 99, 4503-4509. http://dx.doi.org/10.1016/j.biortech.2007.08.063

[16] Dosumu, M.I. and Ochu, C. (1995) Physicochemical Properties and Fatty Acids Composition of Lipids Extracted from Some Nigerian Fruits and Seeds. Global Journal of Pure and Applied Sciences, 1, 45-47.

[17] Anugwa, F.O.I., Okorie, A.U. and Esomonu, A.F.N. (1982) Feed Utilization and Growth of Rabbits Fed Three Levels of Protein and Energy. Nigerian Journal of Nutritional Sciences, 3, 109-114.

[18] Aduku, A.O. and Olukosi, J.O. (1990) Rabbit Management in the Tropics: Production, Processing, Utilization, Marketing, Economics, Practical Training, Research and Future Prospects. Living Book Series, Abuja, 24.

[19] Marcus, V., Mohammed, M.S., Mustapha, M., Igwilo, I. and Gnimintakpa, J. (2014) Extractibility of Thevetia Peruviana Glycoside Using Various Organic Solvents. Journal of Biology, Agriculture and Healthcare, 4, 143-147. 